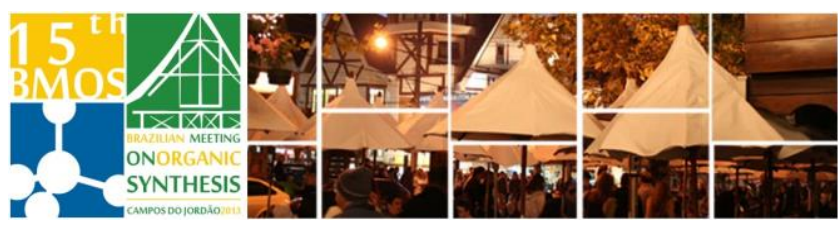

\title{
Synthesis and in vitro antifungal activity of new Mannich bases derived from 2-hydroxy-1,4-naphthoquinone (Lawsone)
}

\author{
Allochio Filho, J. F. ${ }^{1 *}$ Roldi, L. L.; ${ }^{1}$ Fiorot, R.; ${ }^{1}$ Greco, S. J.; $;^{*}$ Lacerda Jr., V.; ${ }^{1}$ dos Santos, R. B.; ${ }^{1}$ de \\ Castro, E. V. R. ${ }^{2}$; Ferreira, J. M. S.; ${ }^{3}$ Aleixo, A. A.; ${ }^{3}$ Carvalho, F. S.; ${ }^{3}$ Carvalho, R. S. ${ }^{3}$ \\ ${ }^{1}$ LSO\&M - Laboratório de Síntese Orgânica e Medicinal. Federal University of Espírito Santo. Vitória, Brazil. \\ ${ }^{2}$ NCQP - Núcleo de Competências em Química de Petróleo. Federal University of Espírito Santo. Vitória, Brazil. \\ ${ }^{3}$ Laboratório de Microbiologia. Federal University of São João Del-Rei. Divinópolis, Brazil. \\ *e-mail: joaoffaf@hotmail.com; sandrogreco.ufes@gmail.com
}

Keywords: Lawsone, triazole, multicomponent Mannich reaction.

\section{INTRODUCTION}

The fungal infection is the one of most very important problem that affects immunocompromised patients due to AIDS and cancer. ${ }^{1}$

Azoles are the most widely antifungal drugs acting on the inhibition of the 14a-demethylase enzyme, very important therapeutic target. ${ }^{2}$ Additionally, the generation of reactive oxygen species (ROS) is very important for antifungal activity and the naphthoquinones, as lawsone, are known compounds with higher capacity to generate ROS. ${ }^{3}$

In this work, we have been synthesized new enolaminas through multicomponent Mannich reaction in lawsone with various aldehydes and amines in ethanol and analyzed the synergy effect of triazole and the ROS.

\section{RESULTS AND DISCUSSION}

In Scheme 1, is shown the scope and procedure of one-pot three-component reaction of 2-hydroxynaphthoquinone (Lawsone, 1).

Scheme 1. Multicomponent Mannich reaction with lawsone.

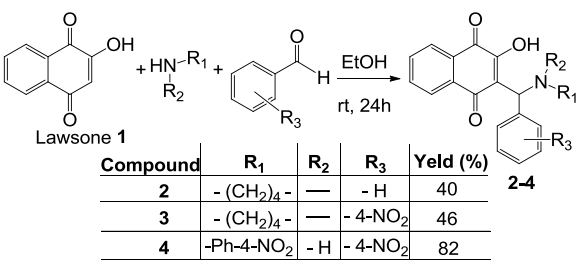

Using the same previous procedure, the reaction of the aldehyde $\mathrm{N}$-phenyl-1,2,3-triazole (6) with lawsone and the amines $\mathbf{7}$ and $\mathbf{8}$, was performed. Unfortunately, rather than obtaining the Mannich adducts 9 , in this reaction was obtained exclusively the compound $\mathbf{1 0}$ and $\mathbf{1 1}$ (Scheme 2).

Scheme 2. Synthesis of N-phenyl-1,2,3-triazole derivatives.

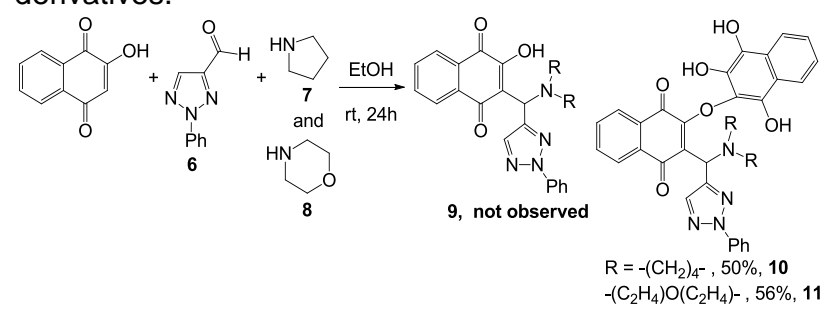

Compounds 10 and 11 were achieved through Michael addition in the respectively Mannich adducts formed in situ and occur due to the very low reactivity of the aldehyde triazolic 6 compared to the aldehydes used in preparation of adducts 2-4.

The synthesized compounds (2-4, 10 and 11) were evaluated for their in vitro antifungal activity against for C. albicans (ATCC 14053), C. glabrata (ATCC 2001) and C. krusei (ATCC 34135).

Table 1. Minimum inhibitory concentration (MIC).

\begin{tabular}{|c|c|c|c|}
\hline \multirow[t]{2}{*}{ Compound } & \multicolumn{3}{|c|}{ MIC ( $\mu \mathrm{g} / \mathrm{mL})$} \\
\hline & C.albicans & C.glabrata & C.krusei \\
\hline 2 & $9,7 \times 10^{-1}$ & - & - \\
\hline 3 & $5,0 \times 10^{-1}$ & - & - \\
\hline 4 & - & - & - \\
\hline 10 & $29,4 \times 10^{-5}$ & - & - \\
\hline 11 & $12,9 \times 10^{-5}$ & - & - \\
\hline Fluconazole & 625 & 19,53 & 78,12 \\
\hline Amphotericin B & 5,0 & $19,5 \times 10^{-1}$ & $2,4 \times 10^{-1}$ \\
\hline $\begin{array}{l}\text { (-) Totally inactive ( } \\
\text { All compound } \\
\text { and high resolut }\end{array}$ & $\begin{array}{l}\mathrm{C} \geq 200 \mu \mathrm{g} / \mathrm{ml} \\
\text { were chara } \\
\text { on mass spe }\end{array}$ & $\begin{array}{l}\text { erized with } \\
\text { trometry. }\end{array}$ & R, NMR \\
\hline
\end{tabular}

The compounds 2-4 was obtained successfully with yields ranging $40-82 \%$ and the triazoles derivatives 10 and 11 was obtained after Mannich reaction followed by Michael addition with yield $50 \%$ and $56 \%$, respectively. The compounds 10 and 11 showed very promise antifungal activity against Candida albicans when compared with the drugs Fluconazole and Amphotericin B, evidencing the synergism between triazole and naphthoquinones.

\section{ACKNOWLEDGEMENTS}

We thank to FAPES, CAPES, CNPq and LabPetroDQUI/UFES for financial support.

\section{REFERENCES}

${ }^{1}$ Turan-Zitouni, G.; Kaplancikli, Z. A.; Yildiz, M. T.; Chevallet, P.; Kaya, D. Eur. J. Med. Chem., 2005, 40, 607-613;

${ }^{2}$ Sheehan, D.J.; Hitchcock, C.A.; Sibley, C.M. Clin. Microbiol. Rev., 1999, 12, 40-79;

${ }^{3}$ Gafner, S.; wolfende, J-L.; Nianga M.; Stoeckli-Evans H.; Hostettmann K. Phytochemistry, 1996, 42, 1315-1320.

$15^{\text {th }}$ Brazilian Meeting on Organic Synthesis - 15 $5^{\text {th }}$ BMOS - November 10-13, 2013 - Campos do Jordão, Brazil 